\title{
Presurgical Nasoalverolar Molding in Fraternal Twins with Bilateral Cleft Lip and/or Palate: A Case Report
}

\author{
Jinsun Kim, Youngjin Kim, Soonhyeun Nam, Hyunjung Kim \\ Department of Pediatric Dentistry,School of Dentistry, Kyungpook National University
}

\section{Abstract}

Cleft lip and palate(CLP) is one of the most common craniofacial deformities that requires systemic management involving a multidisciplinary team approach. Although there has been great improvement in the field of cleft surgery, surgical approach alone cannot resolve the various problems in treating cleft lip and palate. Hence the need for presurgical treatment was appreciated and especially, the concept of presurgical nasoalveolar molding was applied to treat unilateral and bilateral cleft lip and palate patients.

Presurgical nasoalveolar molding(PNAM) of unilateral cleft mainly aims to recover nasal symmetry while the objectives of pre-surgical nasoalveolar molding in the bilateral cleft are to elongate the columella, to erect the tip of nose, and to reposition the forward displaced premaxillary region.

This report covers the case of fraternal twins diagnosed with bilateral cleft. Retraction of the premaxillary region and nasoalveolar molding were conducted for 70 days until cheiloplasty, using elastic bands and nasoalveolar molding appliances. After cheiloplasty, there had been improvements in the length of columella and the position of forward-displaced premaxilla for both patients compared to their initial states. The esthetics was also satisfactory for both the surgery and the parents. In order to maximize the efficacy of the appliance, three components should be in balance; patients' adaptation to the appliance, parents' cooperation and proper selection and careful adjustment of the appliance by the dentist.

Key words : Presurgical nasoalveolar molding(PNAM), Bilateral cleft, Fraternal twins

\section{I. 서 론}

구순/구개열(Cleft Lip and/or Palate)은 선천성 악안면 기 형 중 발생률이 가장 높은 질환이며 한국에서는 1000 명 당 1.81 명의 비율로 발생하는 것으로 보고되고 있다 ${ }^{1)}$. 이는 출생 시기부터 성장이 끝나는 시기까지 기능적, 심미적, 심리적 장애 를 포함한 복합적인 문제를 야기한다.

구순/구개열 환아의 치료는 관련된 여러 전문 분야의 협진 (team approach)을 통해 조직적이고 포괄적인 관리가 필요하 달. 종합적인 치료계획은 환자의 상태나 치료팀에 따라 많은
차이가 있으나 기본 치료 목표는 손상된 해부학적 구조 및 기능 을 회복시키고 심미를 개선시키는데 있다.

구순/구개열 환자가 출생 후 처음으로 직면하는 문제는 수유 장애이며 특히 구개열 환자에서 더욱 문제가 된다. 특수 제작된 우유병이나 obturator 등의 수유 보조 장치를 사용하여 해결할 수 있으며 이를 통해 환아의 정상적인 체중 증가가 이루어져야 이후에 수술이 가능하다. 생후 $10 \sim 12$ 주부터 6 개월 사이에 첫 번째 입술 성형 수술을 시행하며 손상된 입술 주변 근육의 연속 성을 회복시키는 것이 목적이다. 구개 성형 수술 시기에 대해서 는 아직 논란이 있으며, 발음형성 등을 위해 일찍 시행해야 한

\footnotetext{
Corresponding author : Hyunjung Kim

Department of Pediatric Dentistry, School of Dentistry, Kyungpook National University, 2177 Dalgubeol-daero, Jung-gu, 700-412, Korea

Tel: +82-53-600-7211 / Fax: +82-53-426-6608 / E-mail: jungkim@ knu.ac.kr

Received November 1, 2013 / Revised November 28, 2013 / Accepted December 4, 2013

※ This research was supported by Kyungpook National University Research Fund, 2013.
} 
다는 의견과, 수술 반흔으로 인한 중안모 성장에 부정적 영향을 미치므로 천천히 시행하는 것이 좋다는 주장도 있다. 이 후 성 장기 시기에는 발음, 이비인후과적 문제, 치열 교정, 치조골 이 식 등의 치료과정을 거치며 성인기에는 악교정 수술을 동반한 전체적인 교정치료가 진행될 수 있다 ${ }^{3)}$.

구순/구개열은 수술 영역에 있어 많은 발전이 이루어졌으나 수술만으로는 구순/구개열 환자의 다양한 문제점을 해결하는데 한계가 있었다. 그 결과 수술 전 처치의 필요성을 인식하게 되 었고 수술을 통해 파열된 입술과 치조 분절을 폐쇄시킬 때 조직 의 긴장(tension)을 줄이고 반흔 형성을 최소화하기 위한 새로 운 술식이 개발되기 시작했다. 1950 년 $\mathrm{McNeil}$ 에 의해 치조열 부위의 크기를 줄여 이후의 수술을 용이하게 하기 위한 술전 신 생아 정형술(Presurgical infant orthopedics, PSIO)의 개념 이 처음 소개되었으며 지난 60 년간 많은 방법들이 개발되어 제 시되었다 ${ }^{4-6)}$. 이후 1990년대에는 Grayson 등이 PSIO의 개념 에 비연골의 정형 및 비소주(Columella)의 신장까지 포함하여 술전 비치조 정형 (presurgical nasoalveolar molding, $\mathrm{PNAM}$ )장치를 고안하였으며 치조골뿐만 아니라 코의 모양을 정상화하려는 시도가 이루어졌다 ${ }^{7.8}$.

구순/구개열은 크게 편측성과 양측성으로 분류할 수 있으며 그 중 양측성 구순/구개열 환자에서 주된 심미적 문제는 돌출된 전상악부와 짧은 비소주이다. 상악골은 전방의 전상악골(premaxilla)과 양측의 측방구개분절 (lateral palatal segments) 로 나뉘며 전상악골은 좌우의 연속성이 없어 전방으로 돌출된 다. 비첨 (nasal tip)은 납작하고 콧구멍은 가로로 넓적한 형태 이며, 아래가쪽코연골(lower lateral cartilage)은 심하게 변형 되어있다. 그리고 비강저(nasal floor)의 부재도 특징적이다 (Fig. 1). 심한 형태학적 결손은 수술뿐만 아니라 장기적인 결 과에도 영향을 미치는데 환아가 성장함에 따라서 파열부의 봉 합 후 동반되는 반흔에 의해 상악골의 열성장, 좁은 상악궁, 치 아의 선천성 결손, 형태이상, 맹출이상 등이 나타날 수 있다.9.10).

편측성 구순/구개열에서는 코의 대칭성을 만들어 주는 것이 술전 비치조정형장치의 목적이었다면, 양측성 구순/구개열 환 자에게 적용하는 목적은 짧은 비소주를 신장시키고, 낮아진 비 첨의 위치를 높여주면서 동시에 두 콧구멍이 대칭을 이루게 조 절해주어야 한다. 그리고 술전 비치조정형 전에 전방 변위된 전 상악골을 후방이동 시키고 콧구멍에 장치물이 들어갈 공간을 마련하기 위해 탄성밴드를 이용한 전처치가 우선된다. 이를 통 해 입술성형수술 이후에 좀 더 만족스러운 심미적 결과를 가져 올 수 있고 수술 부위의 긴장을 줄여 술 후 반흔 조직을 최소화 할 수 있으며 구개부에 위치하는 레진판은 혀가 파열부위에 접 근하는 것을 방지하고, 수유를 용이하게 한다.

최근에 이러한 술전 비치조정형 장치는 편측성과 양측성 구 순/구개열의 술전 처치에 널리 사용되고 있으며 이 장치의 효과 에 대해서도 다양하게 보고되고 있다. ${ }^{10-13)}$

본 증례는 양측성 구순/구개열로 진단받은 이란성 쌍둥이가 의뢰되어 탄성밴드와 장치물을 이용하여 술전 비치조정형을 시 행하였으며 입술 수술 후 양호한 결과를 얻었기에 이를 보고하
는 바이다.

\section{II. 증 례}

생후 22 일 된 한 쌍의 이란성 쌍둥이가 성형외과로부터 술전 비치조정형을 위해 의뢰되었다. 이 이란성 쌍둥이는 36 주에 제 왕절개를 통해 분만되었으며 첫째 여자아이 $(\mathrm{A})$ 는 양측성 구순 열, 둘째 남자아이 $(\mathrm{B})$ 는 양측성 구순구개열로 진단받았다. 쌍 둥이의 아버지와 할머니가 구순열의 가족력이 있었다. 두 아이 모두 매우 짧은 비소주와 전방 변위된 전상악골 등 전형적인 양 측성 구순/구개열의 특징을 보이고 있었다(Fig. 2).

술전 비치조정형 장치물 (K-Nasoalveolar molding appliance, K-NAM appliance)을 장착하기 전에 탄성밴드를 가로 로 부착시켜 주었다. 이 과정은 전상방으로 변위된 전상악골을 후방견인 시켜주고 K-NAM 장치물이 들어갈 콧구멍의 공간을 확보하기 위해 시행되는 과정이다. 더 큰 유지력을 얻기 위해 머리에 쓰는 모자를 제작하여 사용하였다(Fig. 3).

$\mathrm{K}-\mathrm{NAM}$ 장치물 제작과정은 다음과 같다. 인상 채득 후 얻어 진 석고모형의 언더컷 부위를 왁스로 블록아웃(block out)하 였으며 $\mathrm{A}$ 의 경우 구개열이 동반되어 있어 구개부 파열 부위도 포함시켰다. 분리재 도포 후 교정장치 제작용 레진 및 호선(0.8 $\mathrm{mm}$ )을 이용하여 레진판, 2 개의 유지부(retention arm), 2 개 의 비부(nasal arm)로 구성된 K-NAM 장치를 제작하였다. 비 부의 끝부분에는 레진볼을 작게 형성해주고 이후 비정형시 조 직양화재(tissue conditioner)를 첨가하는 부위로 사용된다. 유지부의 호선 끝은 둥글게 고리를 형성하여 교정용 고무줄을 걸 수 있게 하며 이 고무줄에 스테리스트립(Steri-Strip ${ }^{\mathrm{TM}}$, $3 \mathrm{M}, \mathrm{USA}$ )을 연결하여 환아의 협부에 장치물을 부착시켰다. 레진판의 후방 경계는 경구개와 연구개의 경계부위로 하여 장 착시 환아가 구역질을 하지 않도록 하였다. 레진판의 조직면에 조직양화재를 도포하는데 이는 치조골 정형의 목적 뿐만 아니 라 조직을 보호해주는 역할도 한다(Fig. 4A).이후 비부의 끝부

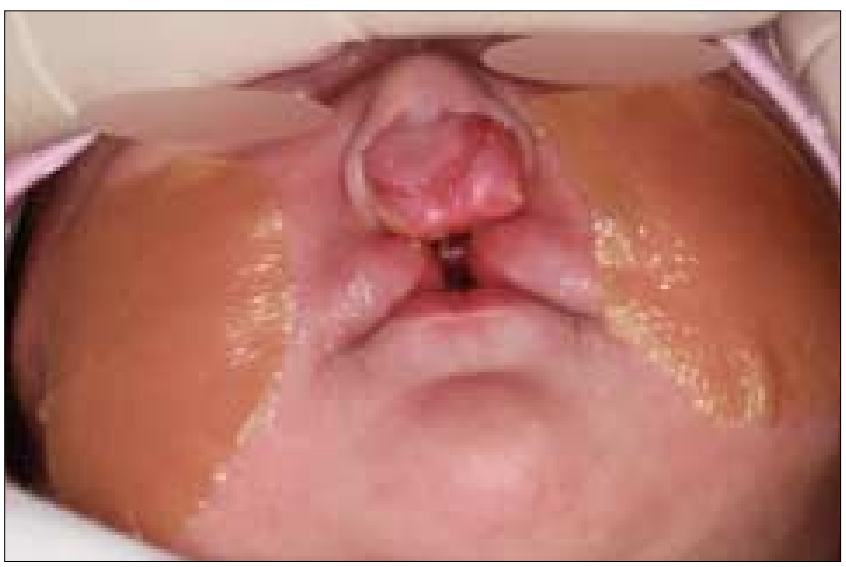

Fig. 1. Bilateral cleft with absent columella, wide nasal tip, protruded premaxilla, and separated lip segments. 

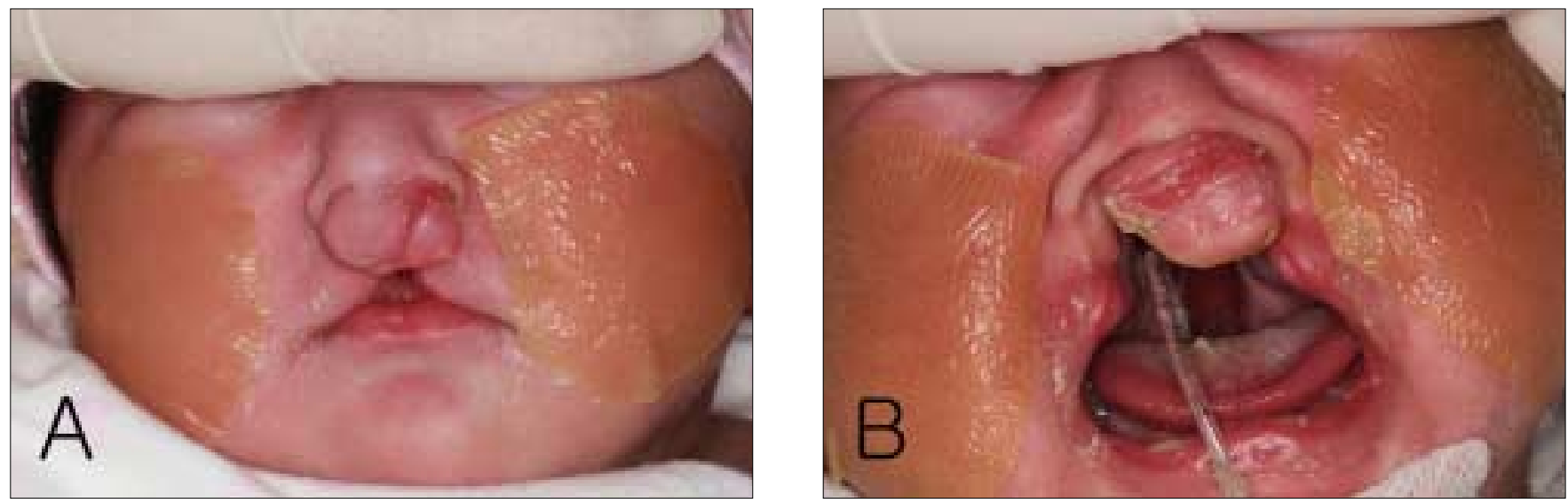

Fig. 2. (A) Extraoral views of patient A(bilateral cleft lip) on the first dental examination. (B) Extraoral views of patient B(bilateral cleft lip and palate) on the first dental examination. He was able to bottle-feed through the tube.

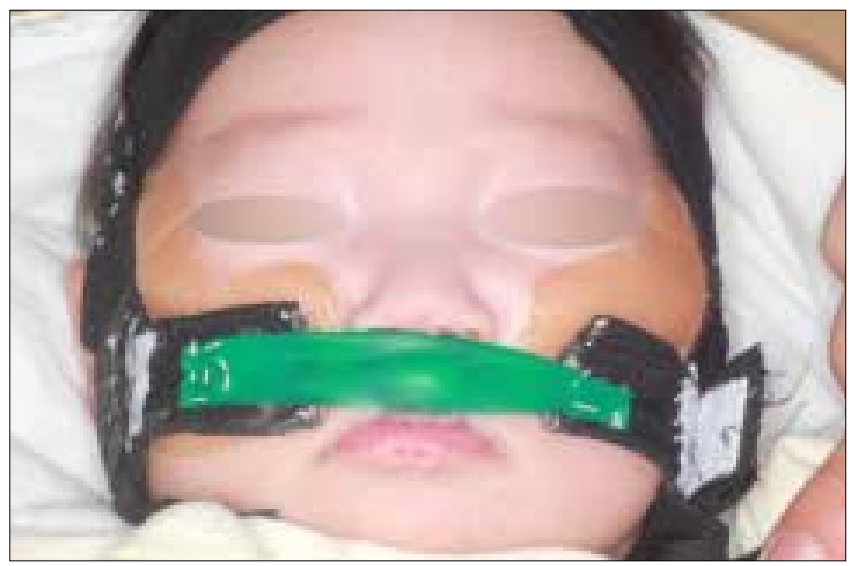

Fig. 3. A patient with a rubber band and head cap.

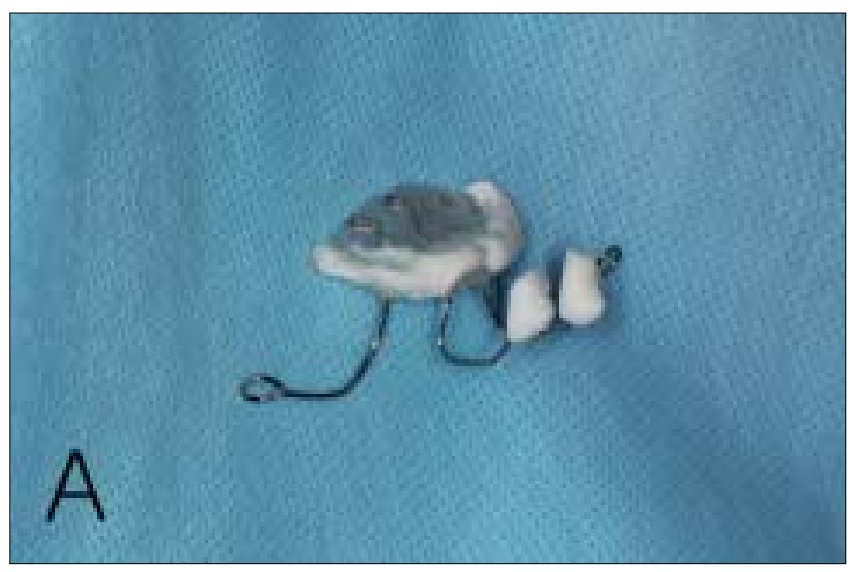

Fig. 4. (A) The K-NAM(K-nasolaveolar molding) appliance for bilateral cleft. (B) Patient with the elastic band and K-NAM appliance. 
이란성 쌍둥이 중 둘째인 남아(B)는 출생시 체중은 $2.9 \mathrm{~kg}$ 이 었고 수유의 어려움으로 인한 입원 치료로 $\mathrm{A}$ 보다 5 일 늦게 내 원하였으며 초진 당시 작은 관(tube)을 통해 우유를 먹고 있는 모습을 관찰할 수 있었다(Fig. 2B). 탄성 밴드 부착 후 생후 47 일이 되는 날 장치물을 장착하였으며 입술성형수술을 시행하기 전까지 총 70 일 동안 8 회의 비정형을 시행하였으며, 이는 $\mathrm{A}$ 보 다 3회 더 많은 횟수이다(Fig. 6).

$\mathrm{B}$ 의 경우 $\mathrm{A}$ 와 달리 구개열이 동반되어 있어 입술성형수술 이 후에 비부를 제거한 K-NAM 장치를 생후 11 개월 경 구개열 수 술 시행 전까지 계속 장착하였다. 레진판 조직면에 조직양화재 를 선택적으로 첨가 및 삭제하고, 수유중 발생되는 입술의 힘을 이용하여 양측의 측방구개분절 사이의 파열부 간격을 줄이고 치조골이 이상적인 형태 및 위치에서 성장할 수 있게 하는 것이 목적이며 또한 환아의 혀가 구개열 사이에 위치하는 것을 방지 하여 감염 방지 및 혀의 위치형성을 돕는 효과도 있다.

술 전후 사진을 통하여 술전 비치조정형을 통해 짧은 비소주 가 신장되고 콧구멍의 형태 및 크기가 개선된 것을 관찰할 수 있었다. 그리고 탄성밴드로 전순과 전상악골을 후방으로 견인 시킴으로써 입술 성형 수술 직전에는 초기에 비해 전방으로의
변위정도가 많이 감소한 것을 석고 모형을 통해 관찰할 수 있었 다(Fig. 7, 8).

$\mathrm{A}$ 와 $\mathrm{B}$ 의 경우 동일한 기간인 약 70 일 동안 $\mathrm{K}-\mathrm{NAM}$ 장치를 장착하였다. 그러나 $\mathrm{B}$ 가 총 8회 비정형을 시행한 반면 $\mathrm{A}$ 의 경 우 적응력의 부족으로 5 회의 비정형을 시행할 수 있었다.

쌍둥이 모두 생후 97일에 성형외과에서 입술 성형 수술을 받 았으며 수술 1 주일 후 내원 시에 양호한 결과를 관찰할 수 있었 다(Fig. 9, 10).

\section{III. 총괄 및 고찰}

심한 구순/구개열을 가진 신생아들의 치료에 있어 술전 비치 조정형술을 시행한 다양한 증례들이 있으며 양호한 결과를 얻 었다는 보고들이 현재까지 계속되고 있다 ${ }^{10-13)}$. 그리고 장기간 관찰한 연구에서 변화된 코의 형태가 안정적이었으며 반흔은 더 적게 형성되었다고 보고되었다 ${ }^{14,15)}$.

양측성 구순/구개열의 경우 편측성에 비해 술전 비치조정형 과정이 더 복잡한데 이는 서로 다른 해부학적 특징을 가지기 때 문이다. 편측성 구순/구개열의 경우 파열부의 짧아진 비소주로
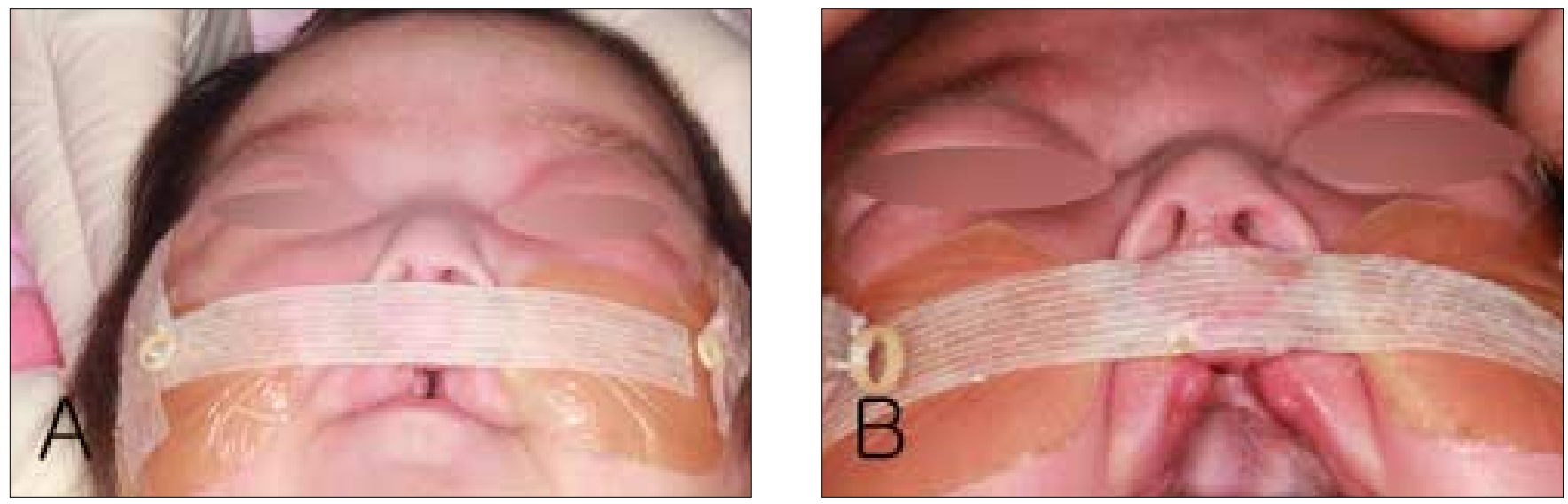

Fig. 5. Extraoral views of patient $A$ on the second(A) and fifth(B) moldings.
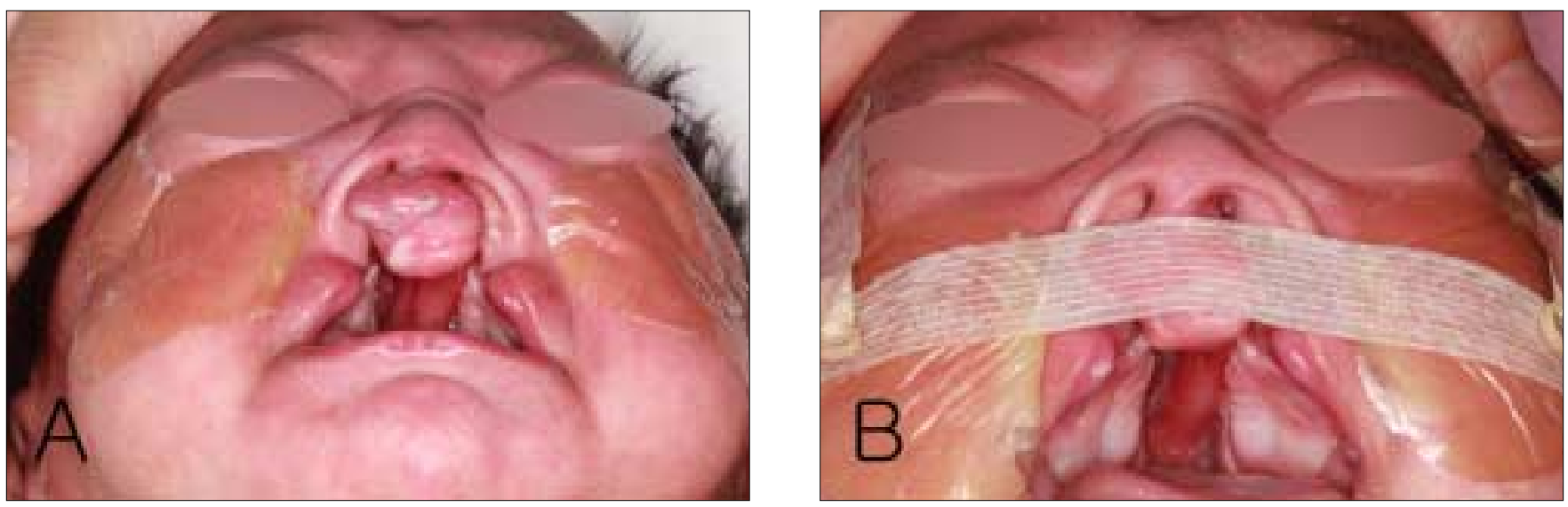

Fig. 6. Extraoral views of patient $B$ on the second(A) and eighth(B) nasal moldings. 


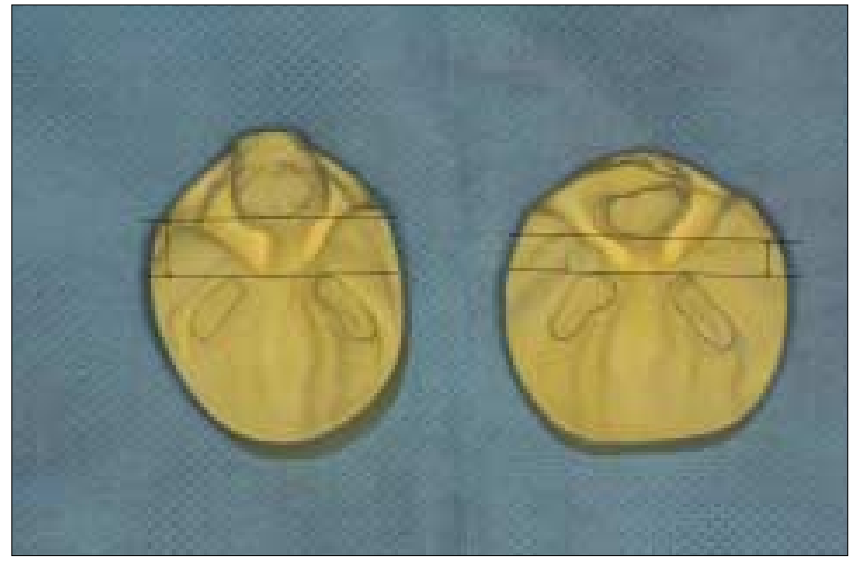

Fig. 7. Dental models of patient A taken on the first visit(Left) and after presurgical nasoalveolar molding procedure(Right). Note that the previously protruded premaxilla has been migrated backward.

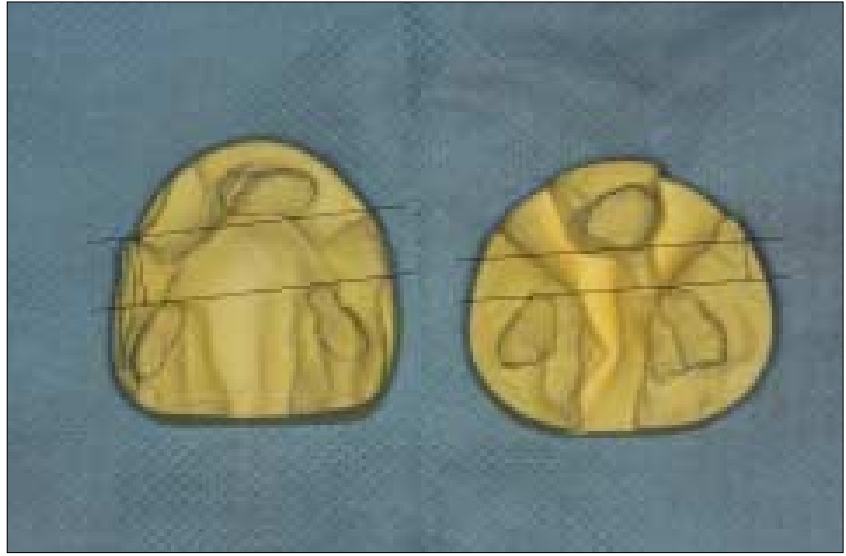

Fig. 8. Dental models of patient $B$ taken on the first visit(Left) and after presurgical nasoalveolar molding procedure(Right). Note that the previously protruded premaxilla has been migrated backward.
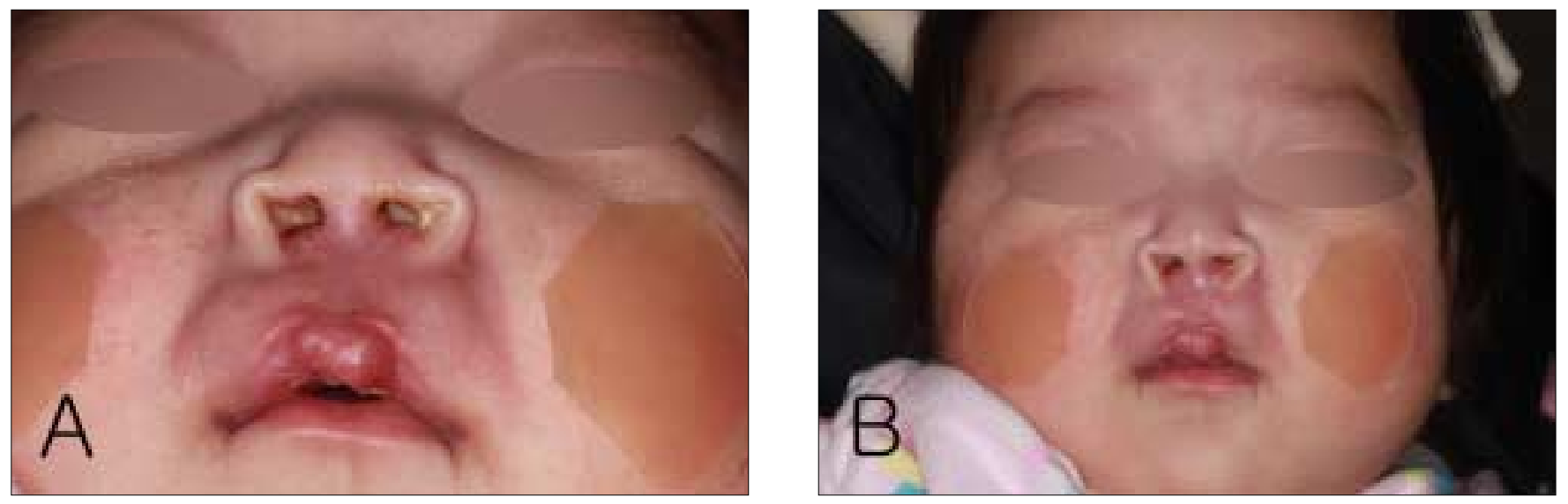

Fig. 9. Patient A, one week after cheiloplasty.
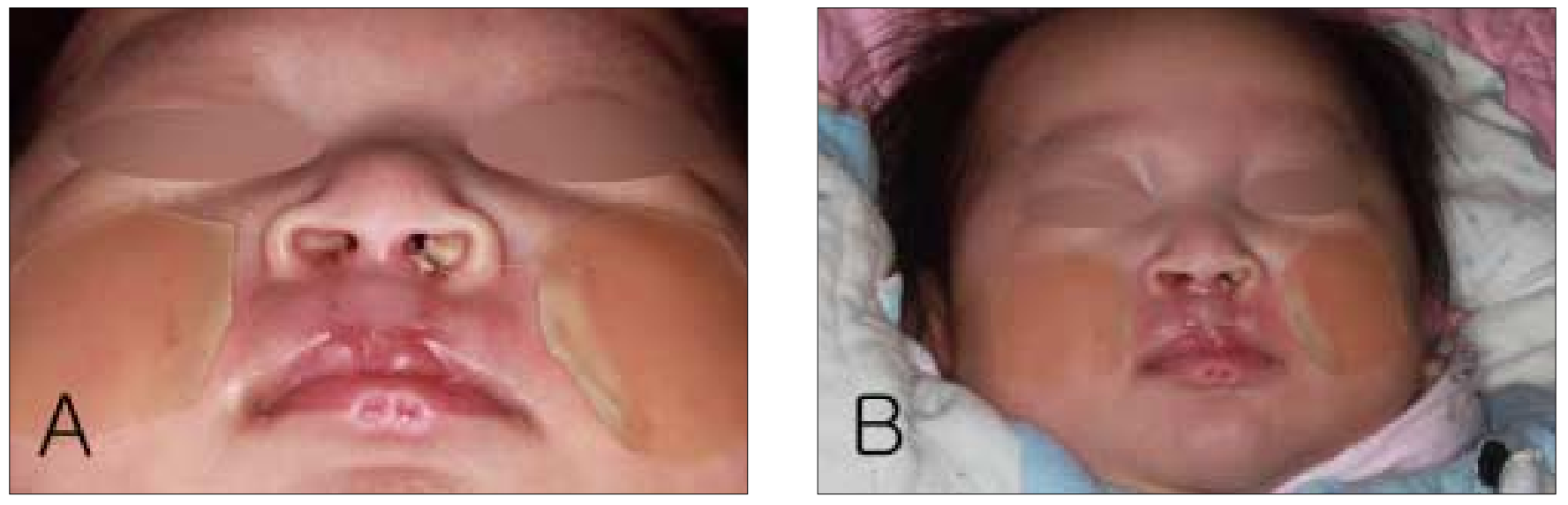

Fig. 10. Patient B, one week after cheiloplasty. 


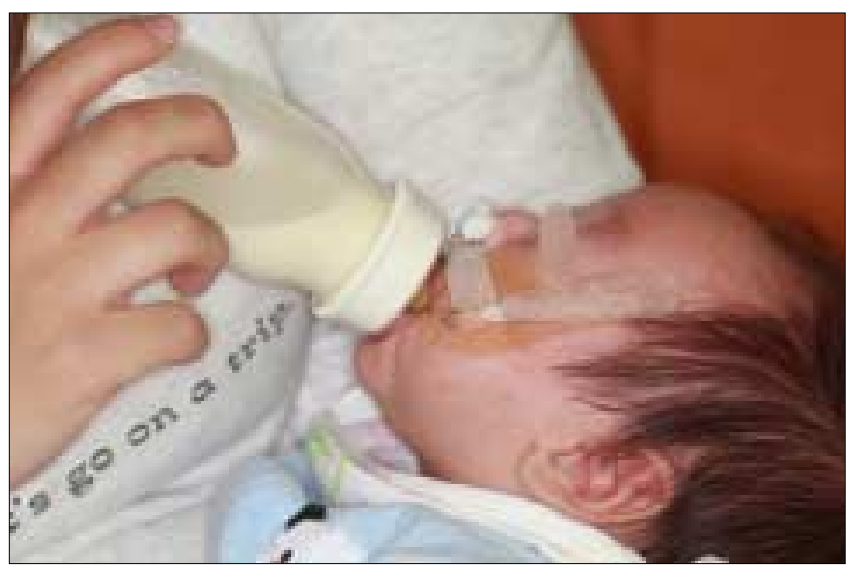

Fig. 11. Patient B, bottle feeding with K-NAM appliance.

인해 비대칭적인 코의 형태가 주된 특징이므로 이환된 쪽의 낮 아지고 옆으로 평평해진 코의 형태를 반대측과 대칭성을 이루 게 하는 것에 주안을 둔다. 그에 반해 양측성 구순/구개열 환자 의 매우 짧은 비소주로 인해 코끝이 납작하고 전순과 전상악골 이 전방변위 되어 있는 것이 특징이다. 이로 인해 술전 비치초 정형 장치를 장착할 수 없는 경우 탄성밴드를 이용하여 전방 변 위된 전상악골을 후방 이동시키면서 장치물이 들어갈 수 있는 공간을 마련하는 과정이 먼저 필요하다. 이 후 짧은 비소주를 신장시키고 납작해진 비첨의 위치를 높게 개선시키며 그와 동 시에 계속적으로 전순과 전상악골을 후방견인 해주어야 한다. 따라서 장치물이 복잡해지고 장치물의 조정도 더 자주 필요하 게 된다.

이 증례에서 사용한 K-NAM 장치는 기존의 Obturator나 술 전 비치조정형 장치물의 디자인을 약간 변형시킨 형태로 유지 부와 비부가 교정용 호선으로 만들어져 장치물의 부피를 감소 시킬 수 있고 치료 과정에 따라 계속적으로 변화하는 환아의 구 강조직에 적합하도록 조작하는 과정이 간단하다. 또한 $\mathrm{K}-\mathrm{NAM}$ 장치는 탄성밴드와 독립적으로 장착하므로 환아의 구강조직의 변화에 따라 장치의 조절이 자유롭다는 장점을 갖고 있다.

태생 직후 신생아의 연골에는 estrogen과 hyaluronic acid 가 높은 수준으로 분포하고 있어 높은 가소성과 낮은 탄성력을 가지고 있다. 따라서 어떤 압력이 가해졌을 때 쉽게 정형적 효 과를 얻을 수 있다. 그러나 출생 후 시간이 지나면 비연골의 가 소성이 점점 감소하기 때문에 능동적인 비연골의 정형은 생후 $2 \sim 3$ 개월 까지만 가능하다 ${ }^{16,17)}$. 따라서 치료 시작 시기는 빠를 수록 좋으며 입술 성형 수술을 하기 전까지 한정된 기간 동안 최대한의 효과를 얻을 수 있도록 해야한다.

이번 증례에서는 장치물 장착 시기 및 기간, 같은 보호자 등 거의 동일한 조건으로 장치물 장착을 시작하였다. 쌍둥이 남아 인 $\mathrm{B}$ 의 경우 구개열을 동반한 양측성 구순열로 장치물 장착 전 에는 수유의 어려움으로 체중이 오히려 감소하였으나 장치물 장착 이후 수유가 가능해지고 계획한 만큼의 비정형이 가능하
였으며 입술성형수술 이후에도 양호한 결과를 나타내었다. 그 러나 쌍둥이 여아인 $\mathrm{A}$ 의 경우 감기로 인해 장치물의 장착에 어 려움이 있었고 장치물이 닿는 부위에 입술 부종이 생겨 비정형 을 3회 생략했다. 이 증례를 통해 $\mathrm{K}-\mathrm{NAM}$ 의 효과적인 적용에 환아의 적응력이 미치는 영향을 엿볼 수 있었다는 점에 의의가 있다. 환아의 적응 정도 뿐만 아니라 구강 내 부종이나 염증부 위가 생기지 않도록 보호자와 술자의 세심한 관찰 및 장치물 조 정의 필요할 것이다.

술전 비치조정형 장치는 코 형태의 성형뿐만 아니라 구강 내 에 음압을 형성할 수 있게 하며 수유에도 도움이 된다. 그리고 구강 내 음압 형성은 환아가 젖병을 빠는 행위를 가능하게 하므 로 이를 통해 구강 주변조직이 정상적으로 발달하는 데에도 도 움을 줄 수 있다. 구강 내에 음압이 형성되지 않으면 흡입력과 연하력이 저하되어 공기가 과도하게 흡입되어 구토를 유발하는 문제점이 있다. 그리고 특히 구개열을 동반한 경우 비강으로 우 유가 유입되어 질식 등을 일으킬 위험도 있다 ${ }^{18)}$. 대부분의 구순 구개열 환아는 출생 직후부터 충분한 양의 수유를 할 수가 없어 정상적인 체중 변화 패턴을 보이지 않는 경우가 많으며 이 때문 에 성형수술을 연기하게 되는 경우도 있다 ${ }^{19}$. 이번 증례에서 출 생 시 $\mathrm{A}$ 는 $2.8 \mathrm{~kg}, \mathrm{~B}$ 는 $2.9 \mathrm{~kg}$ 이었고 구개열을 동반한 $\mathrm{B}$ 의 경 우 수유의 어려움으로 출생 후 16 일 경에 응급실에 내원했을 때 $2.7 \mathrm{~kg}$ 까지 감소한 상태였으며 튜브를 통해 수유를 하고 있 었다. 그러나 K-NAM 장치물을 장착한 첫 날부터 환아 스스로 젖병을 빠는 것이 가능하게 되었다(Fig. 11). K-NAM 장치를 장착한 후 17 일째 되는 날 $\mathrm{A}, \mathrm{B}$ 의 체중은 각각 $4.3 \mathrm{~kg}, 4.1 \mathrm{~kg}$ 이었고 45 일째 되는 날에는 각각 $5.05 \mathrm{~kg}, 5.12 \mathrm{~kg}$ 로 B의 체 중이 정상적으로 증가한 것을 알 수 있었다. 환아가 수술을 받 기 위한 상태까지 성장하는 데에 적절한 수유는 필수적이며이 K-NAM 장치는 교정용 호선으로 제작되어 젖병을 무는데 방해 가 되지 않으므로 비정형과 동시에 수유도 가능하다는 장점이 있다.

이번 증례의 쌍둥이는 친할머니와 아버지에게 구순열 가족력 이 있는 것으로 보아 구순/구개열 발생 원인으로 유전적 요인의 작용을 예측할 수 있으나, 이란성 쌍둥이이고 각각 양측성 구순 열과 양측성 구순구개열이 나타난 것으로 보아 환경적인 요인 의 작용도 배제할 수 없다. 더 많은 수의 증례가 수집되고 구순/ 구개열을 가진 일란성 쌍둥이, 쌍둥이가 아닌 형제의 증례까지 추가된다면 구순/구개열 발생에 미치는 유전 및 환경적 요인에 대한 더 자세한 연구가 가능하게 될 것이다.

\section{IV. 요 약}

구순/구개열 환자가 직면하는 여러 문제점을 해결하는데 있 어 수술만으로는 한계가 있으며, 수술을 더욱 용이하게 하고 개 선된 심미적인 결과를 얻기 위해 술전 비치초정형술이 개발되 어 사용되고 있다.

각각 양측성 구순열 및 양측성 구순구개열로 진단받은 이란 성 쌍둥이가 성형외과로부터 술전 비치조정형을 위해 의뢰되어 
내원하였다. 양측성 구순/구개열의 특징인 짧은 비소주와 전방 변위된 전상악부의 수술 전 처치를 위해 탄성 밴드와 $\mathrm{K}-\mathrm{NAM}$ 장치를 함께 사용하여 술전 비치조정형을 시행하였다. 돌출되 었던 전상악부의 위치가 개선되고 짧았던 비소주가 신장된 결 과를 관찰할 수 있었고, 입술성형수술 이후 심미적으로 만족스 러운 결과를 보였다. 또한 쌍둥이에게 적용함으로써 장치물 장 착에 있어 환아의 적응 정도, 보호자의 협조도 및 술자의 세심 한 관찰과 조정의 필요성도 알 수 있었다.

\section{References}

1. Kim S, Kim WJ, Oh C, Kim JC : Cleft lip and palate incidence among the live births in the republic of Korea. J Korean Med Sci, 17:49-52, 2002.

2. Jaju R, Tate AR : The role of pediatric dentistry in multidisciplinary cleft palate teams at advanced pediatric dental residency programs. Pediatr Dent, May-Jun;31:188-92, 2009.

3. Angus C Cameron, Richard P Widmer : Handbook of Pediatric Dentistry, 4th ed. Mosby, 447-461, 2013.

4. McNeil C : Orthodontic procedures in the treatment of congenital cleft palate. Dent Record, 70:126-132, 1950.

5. Burston WR : The early orthodontic treatment of alveolar clefts. Proc R Soc Med, 58:767-772, 1965.

6. Hotz MM : Pre-and early postoperative growthguidance in cleft lip and palate cases by maxillary orthopedics. Cleft Palate J, 6:368-372, 1969.

7. Grayson BH, Santiago PE, Brecht LE, Cutting CB : Presurgical nasoalveolar molding in infants with cleft lip and palate. Cleft Palate Craniofac J, Nov;36: 486-98, 1999.

8. Grayson BH, Cutting C, Wood R : Preoperative columella lengthening in bilateral cleft lip and palate. Plast Reconstr Surg, 92:1422-1423, 1993.

9. Singh AK, Nandini R : Bilateral cleft lip nasal deformity, Indian J Plast Surg, Jul; 42:235-241, 2009.

10. Grayson BH, Maull D : Nasoalverolar molding for infants born with clefts of the lip, alveolus, and palate. Clin Plast Surg, 31:149-158, 2004.

11. Meazzini MC, Rossetti G, Brusati R, et al. :
Photometric evaluation of bilateral cleft lip and palate patients after primary columella lengthening. Cleft Palate Craniofac J, 47:58-65, 2010.

12. Lee CT, Garfinkle JS, Grayson BH, et al. : Nasoalveolar molding improves appearance of children with bilateral cleft lip-cleft palate. Plast Reconstr Surg, 122:1131-1137, 2008.

13. Garfinkle JS, King TW, Cutting CB, et al. : A 12year anthropometric evaluation of the nose in bilateral cleft lip-cleft palate patients following nasoalveolar molding and cutting bilateral cleft lip and nose reconstruction. Plast Reconstr Surg, 127:1659-1667, 2011.

14. Maull DJ, Grayson BH, Hurwitz DJ, et al. : Longterm effects of nasoalveolar molding on three-dimensional nasal shape in unilateral clefts. Cleft Palate Craniofac J, 36:391-397, 1999.

15. Patil PG, Patil SP, Sarin S : Nasoalveolar molding and long-term postsurgical esthetics for unilateral cleft lip/palate: 5-year follow-up. J Prosthodont, 20:577-582, 2011.

16. Matsuo K, Hirose T, Tonomo T : Nonsurgical correction of congenital auricular deformities in the early neonate: a preliminary report. Plast Reconstr Surg, 73:38-50, 1984.

17. Grayson BH, Cutting CB : Presurgical nasoalveolar orthopaedic molding in primary correction of the nose, lip and alveolus of infants born with unilateral and bilateral clefts. Cleft Palate Craniofac J, 38: 193-198, 2001.

18. Reid J, Kilpatrick N, Reilly S : A prospective, longitudinal study of feeding skills in a cohort of babies with cleft conditions. Cleft Palate Craniofac J, 43: 702-709, 2006.

19. Avedian LV, Ruverg RL : Impaired weight gain in cleft palate infants. Cleft palate J, Jan;17:24-26, 1980.

20. Hong SJ, Choi YC, Lee KH : The effect of obturator for cleft lip and palte infants: A Case Report. $J$ Korean Acad Pediatr Dent, 24:352-360, 1997. 
국문초록

\title{
양측성 구순/구개열을 가진 이란성 쌍둥이를 대상으로 한 술전 비치조정형술: 증례보고
}

\author{
김진선 · 김영진 · 남순현 · 김현정
}

경북대학교 치의학전문대학원 소아치과학교실

구순구개열은 선천성 악안면 기형 중 발생률이 가장 높은 질환으로 관련된 여러 분야의 협진(team approach)을 통한 조 직적인 관리를 필요로 한다. 치료에 있어 수술분야의 많은 발전이 있어 왔으나 수술만으로는 다양한 문제점을 해결하기 어려 웠다. 이에 따라 술 전 처치의 필요성을 인식하여 술전 비치조 정형의 개념이 개발되었으며 편측성 및 양측성 구순구개열 환 자에게 적용되고 있다.

편측성 구순구개열에서 술전 비치조정형의 목적을 코의 대칭성을 회복시키는데에 중점을 두었다면 양측성 구순구개열에서 는 짧은 비소주를 신장시키고, 낮아진 코끝을 세우고, 전방으로 변위된 전상악부를 재위치 시키는 것이 목적이라 할 수 있다.

본 증례에서는 양측성 구순/구개열로 진단받은 이란성 쌍둥이에게 술전 탄성밴드와 비치조정형 장치를 이용하여 첫 번째 입술수술 전까지인 약 70일간 전상악부의 후방 견인 및 술전 비치조정형을 시행하였다. 두 환아 모두 초기에 비해 비소주가 길어지고 전방 변위된 전상악부가 제 위치로 많이 회복된 것을 관찰할 수 있었다. 그리고 입술 수술 후 술자와 보호자가 모두 만족할만한 심미적인 결과를 얻을 수 있었다. 장치의 효과를 극대화하기 위해서 환자의 적응력, 보호자의 협조도 및 술자의 적절한 장치물의 선택과 세심한 조정, 이 3 가지 요소가 조화를 이루어야 할 것이다.

주요어: 술전 비치조정형, 양측성 구순구개열, 이란성 쌍둥이 